BRAVZILILAN JOURNAL

OF MEDICAL AND BIOLOGICAL RESH.ARCH

www.bjournal.com.br
ISSN 0100-879X

Volume 43 (10) 914-1009 October 2010

BIOMEDICAL SCIENCES

AND

CLINICAL INVESTIGATION

Braz J Med Biol Res, October 2010, Volume 43(10) 989-995

doi: 10.1590/S0100-879X2010007500093

A safety and feasibility study of cell therapy in dilated cardiomyopathy

H.F. Martino, P.S. Oliveira, F.C. Souza, P.C. Costa, E. Assunção e Silva, R. Villela, M. Gaze, L.H. Weitzel, A. Oliveira Jr., F.B. Muccillo, S.N.S. Arvelo, R. Sá, T.C.F. Guimarães, B.R. Tura and A.C. Campos de Carvalho

The Brazilian Journal of Medical and Biological Research is partially financed by
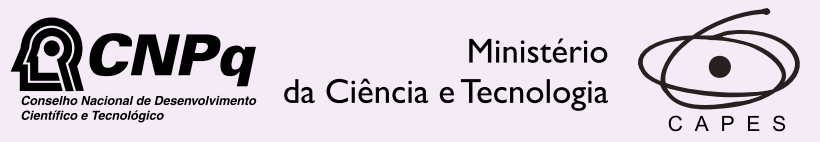

Ministério da Educação

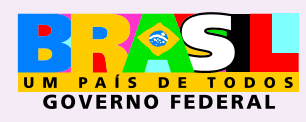

DTAPESP

Institutional Sponsors

Hotsite of proteomics metabolomics developped by: 


\title{
A safety and feasibility study of cell therapy in dilated cardiomyopathy
}

\author{
H.F. Martino ${ }^{1}$, P.S. Oliveira ${ }^{2}$, F.C. Souza ${ }^{3}$, P.C. Costa ${ }^{4}$, E. Assunção e Silva ${ }^{5}$, \\ R. Villela ${ }^{1}$, M. Gaze ${ }^{1}$, L.H. Weitzel ${ }^{6}$, A. Oliveira Jr. ${ }^{10}$, F.B. Muccillo ${ }^{4}$, S.N.S. Arvelo ${ }^{4}$, \\ R. Sá ${ }^{7}$, T.C.F. Guimarães ${ }^{4}$, B.R. Tura ${ }^{8}$ and A.C. Campos de Carvalho ${ }^{9}$ \\ ${ }^{1}$ Setor de Cardiomiopatia, ${ }^{2}$ Setor de Hemodinâmica, ${ }^{3}$ Setor de Ergometria, ${ }^{4}$ Laboratório de Terapia Celular, \\ ${ }^{5}$ Setor de Hematologia, ${ }^{6}$ Setor de Ecocardiografia, ${ }^{7}$ Setor de Arritmias, ${ }^{8}$ Setor de Bioestatística e Bioinformática, \\ ${ }^{9}$ Coordenação de Ensino e Pesquisa, Instituto Nacional de Cardiologia, Rio de Janeiro, RJ, Brasil \\ 10 Setor de Imagem, Hospital Pró-Cardíaco, Rio de Janeiro, RJ, Brasil
}

\begin{abstract}
The aim of this study was to determine if bone marrow mononuclear cell (BMMC) transplantation is safe for moderate to severe idiopathic dilated cardiomyopathy (IDC). Clinical trials have shown that this procedure is safe and effective for ischemic patients, but little information is available regarding non-ischemic patients. Twenty-four patients with IDC, optimized therapy, age $46 \pm$ 11.6 years, 17 males, NYHA classes II-IV, and left ventricular ejection fraction $<35 \%$ were enrolled in the study. Clinical evaluation at baseline and 6 months after stem cell therapy to assess heart function included echocardiogram, magnetic resonance imaging, cardiopulmonary test, Minnesota Quality of Life Questionnaire, and NYHA classification. After cell transplantation 1 patient showed a transient increase in enzyme levels and 2 patients presented arrhythmias that were reversed within $72 \mathrm{~h}$. Four patients died during follow-up, between 6 and 12 weeks after therapy. Clinical evaluation showed improvement in most patients as reflected by statistically significant decreases in Minnesota Quality of Life Questionnaire (63 \pm 17.9 baseline vs $28.8 \pm 16.75$ at 6 months) and in class III-IV NYHA patients (18/24 baseline vs 2/20 at 6 months). Cardiopulmonary exercise tests demonstrated increased peak oxygen consumption (12.2 \pm 2.4 at baseline vs $15.8 \pm 7.1 \mathrm{~mL} \cdot \mathrm{kg}^{-1} \cdot \mathrm{min}^{-1}$ at $\left.6 \mathrm{months}\right)$ and walked distance (377.2 \pm 85.4 vs $444.1 \pm 77.9 \mathrm{~m}$ at 6 months) in the 6 -min walk test, which was not accompanied by increased left ventricular ejection fraction. Our findings indicate that BMMC therapy in IDC patients with severe ventricular dysfunction is feasible and that larger, randomized and placebo-controlled trials are warranted.
\end{abstract}

Key words: Bone marrow cells; Mononuclear fraction; Autologous transplantation; Ejection fraction; Treadmill test; Dilated cardiomyopathy

\section{Introduction}

Dilated cardiomyopathy is the most common form of nonischemic cardiomyopathy, characterized by ventricular dilatation, cardiomyocyte death, thinning of chamber walls, and fibrosis (1-3). Despite optimized pharmacological therapy, patients with dilated cardiomyopathy frequently progress to end-stage heart failure. For these patients, the only available therapy is heart transplantation, which is limited to a very small number of patients. Therefore, new therapeutic options for these patients are urgently needed.

In preclinical models, cardiovascular stem cell therapy has been used successfully in a variety of cardiac diseases, including dilated cardiomyopathy (4-9). In the clinical setting, cell therapies have been previously used in patients with ischemic heart disease, both in the acute and chronic stages. In most trials, the mononuclear fraction of bone marrow has been used, but a variety of cell types from bone marrow and skeletal myoblasts have also been delivered to patients (10-17). Results have demonstrated excellent safety with encouraging signs of clinical improvement (1012,14-17).

Very few studies have applied cell therapy to patients with non-ischemic dilated cardiomyopathy (18-21), and conflicting results as to the safety of the procedure have been reported.

Based on these findings and given the limited therapeutic options for refractory dilated cardiomyopathy, we decided to perform a phase I clinical trial using bone marrow mononuclear cells (BMMC) in idiopathic dilated cardiomyopathy

Correspondence: A.C. Campos de Carvalho, Laboratório de Terapia Celular, Instituto Nacional de Cardiologia, Rua das Laranjeiras, 374/5ํandar, 22240-006 Rio de Janeiro, RJ, Brasil. E-mail: acarlos@biof.ufrj.br

Received April 13, 2010. Accepted September 1, 2010. Available online September 17, 2010. Published October 18, 2010. 
patients with functional classes II-IV of the New York Heart Association (NYHA).

\section{Material and Methods}

\section{Patients}

From February 2005 through August 2006 we enrolled 24 patients with optimized therapy and a diagnosis of idiopathic dilated cardiomyopathy (IDC) according to World Health Organization criteria. Inclusion criteria required left ventricular ejection fraction (LVEF) (Simpson) $<35 \%$, peak oxygen consumption $\left(\mathrm{VO}_{2}\right.$ peak $)<16 \mathrm{~mL} \cdot \mathrm{kg}^{-1} \cdot \mathrm{min}^{-1}$, functional classes II-IV of NYHA, signed informed consent, and ages between 18 and 70 years. Exclusion criteria were: coronary artery disease based on coronary angiography prior to cell delivery, dilated cardiopathies of ischemic or chagasic origin, primary valve disease, excessive use of alcohol or illicit drugs, pregnancy, ventricular arrhythmias, and any co-morbidity with impact on survival. The study complied with Declaration of Helsinki regulations (1975), reviewed in Edinburg (2000). The Ethics Review Board of the National Cardiology Institute approved the protocol that was registered by the National Ethics Committee (CONEP - registration No. 9287). The study was also registered in ClinicalTrials.gov (registration No. NCT00612911).

\section{Study design}

Patients underwent the following exams at baseline and 6 months after cell therapy: chest X-ray, blood biochemistry, 12-lead electrocardiogram (ECG) and 24-h Holter, echocardiography, B-type natriuretic peptide (BNP, Biosite Inc., USA), cardiopulmonary exercise testing (CPET), magnetic resonance imaging (MRI), 6-min walk test, NYHA classification, and Minnesota Quality of Life Questionnaire. Patients were followed for 6 months after cell therapy at the outpatient clinic for cardiomyopathy of the National Cardiology Institute. The safety endpoints were any complications related to the cell injection procedure including levels of cardiac enzyme (troponin t), ventricular arrhythmias, conduction disturbances, and death by any cause. Patients underwent bone marrow aspiration (80-100 $\mathrm{mL}$ from the iliac crest) under sedation and local anesthesia. BMMC were obtained after Ficoll gradient centrifugation. After extensive washing in saline with autologous serum, cells were diluted in $20 \mathrm{~mL}$ saline containing $5 \%$ autologous serum and were slowly delivered to the coronary arteries by cardiac catheterization $(10 \mathrm{~mL}$ in the left anterior descending artery, $5 \mathrm{~mL}$ in the circumflex artery and $5 \mathrm{~mL}$ in the right coronary). The aspiration and cell preparation procedure lasted 2 to $2.5 \mathrm{~h}$. Intracoronary cell delivery was performed right after cell preparation and the time spent in the catheterization laboratory was approximately $1 \mathrm{~h}$, after which patients were taken to the Intensive Care Unit for 24 $h$ with continuous monitoring of ECG and periodic measurements of enzyme levels. Patients remained hospitalized for a total of $72 \mathrm{~h}$ and were then discharged for home. A portion of the cell suspension was used for the determination of percent $\mathrm{CD} 34^{+}$cells in the mononuclear fraction using the ISHAGE protocol (22) and a FACS-Canto instrument (BD Biosciences, USA).

\section{Echocardiography}

Echocardiographic studies were conducted according to the American Society of Echocardiography. Global LVEF was calculated from measurements of left ventricular end diastolic and end systolic volumes in apical 4 and 2 chamber views using Simpson's rule and a Vivid 7 echocardiograph (GE Healthcare, UK).

\section{Cardiopulmonary exercise testing}

CPET was performed using a treadmill ramp protocol. Patients were encouraged to exercise until exhaustion or when limited symptoms were detected. Standard 12-lead electrocardiograms were obtained at rest, each minute during exercise, and for at least 5 min during the recovery phase. Blood pressure was measured with a standard sphygmomanometer. $\mathrm{VO}_{2}$ peak was defined as the highest $\mathrm{VO}_{2}$ observed during the last minute of exercise. Minute ventilation (VE), oxygen uptake $\left(\mathrm{VO}_{2}\right)$ and carbon dioxide output $\left(\mathrm{VCO}_{2}\right)$ were analyzed at rest and every $20 \mathrm{~s}$ with a $\mathrm{VO}_{2000}$ analyzer (MedGraphics, USA). VE and $\mathrm{VCO}_{2}$ values were used to calculate the $\mathrm{VE} / \mathrm{VCO}_{2}$ slope via least squares linear regression.

\section{Magnetic resonance imaging}

MRI was performed using a $1.5 \mathrm{~T}$ Echo Speed Plus instrument (GE Healthcare). Left ventricle volumes and LVEF were calculated using the GE Software (Mass Analysis Plus V4.0.1, for Advantage Windows 4.0, and Report Card 3.0, for ADW 4.3). Short and long axis cine views were acquired throughout the entire volume of the left ventricle. The short axis views were used for the volume and LVEF calculations. Typically the short axis slices were 8-mm thick, with a 2-mm gap.

\section{Statistical analysis}

Data were analyzed using the $\mathrm{R}$ software version 2.6.1 (23). We used the Shapiro test to determine if normal distribution was applicable to the variables. Normally distributed continuous variables are reported as means \pm SD. When distribution was not normal, the median and inter-quartile interval were used to present the data. Because we were interested in measuring differences between baseline and each time, data from patients who died during follow-up were excluded from the analysis. Due to the small number of patients, longitudinal comparison of continuous variables was performed by the paired Student $t$ or Wilcoxon test but $P$ values for the analysis were adjusted by the Bonferroni post-test. Categorical variables were evaluated by the Fisher exact test. We considered $95 \%$ as the confidence level. 


\section{Results}

\section{Cell characterization}

From $80-100 \mathrm{~mL}$ of marrow aspirate we obtained $177 \pm$ 125 million (range of 58 to 620 million) mononuclear cells with $98 \pm 1.12 \%$ viability (Trypan exclusion). All cells, except for a small aliquot used for cytometry, were injected in the patients. Flow cytometry analysis (BD Facs-Canto) showed that the injected mononuclear fraction contained a mean of $1.3 \pm 0.7 \% \mathrm{CD}^{2} 4^{+}$cells (ISHAGE Protocol).

\section{Baseline characteristics of the patients}

Key demographic characteristics of the 24 patients are listed in Table 1. Optimized pharmacological therapy included $\beta$-blockers, angiotensin-converting enzyme inhibitors and diuretics before enrollment, and was kept throughout the end of the study except for necessary adjustments of diuretic doses.

\section{Safety evaluation}

During the cell injection procedure one patient developed a transient right bundle branch blockage (RBBB), one patient had atrial fibrillation (AF) that was reversed with amiodarone within $8 \mathrm{~h}$, and one patient showed an elevation in troponin I enzyme levels from 0.5 to 3.312 $\mathrm{h}$ after cell injection, without pain, ECG or hemodynamic instability that normalized within $72 \mathrm{~h}$. No other patient had an increase in cardiac enzymes.

Four patients died during the 6-month follow-up. The deaths occurred on the 48th, 52nd, 57th, and 86th day after cell injection. One patient died of sepsis during hospitalization for digitalis intoxication. Two other deaths were caused by acute cardiogenic pulmonary edema and cardiogenic shock, respectively. All 3 deaths were thus considered to be unrelated to the procedure. The cause for the last death was undetermined. The patient died at home in his sleep, and arrhythmias related to cell injection leading to sudden cardiac death could not be ruled out. Unfortunately, no autopsies were authorized by the families.

\section{Clinical evaluation}

There were no significant differences in mean weight, arterial pressure, heart rate, or blood biochemistry including hemoglobin, sodium, potassium, creatinine, and albumin levels during the course of the study. ECGs performed during the $72 \mathrm{~h}$ of patient hospitalization for the procedure revealed no alterations other than those described in the above safety evaluation (one AF and one RBBB). The number of ventricular ectopic beats detected during the 24-h Holter monitoring was not significantly different at baseline [235.5 (84.0 to 725.0, median and interquartile interval)], 2 months [110.0 (21.5 to 1016)], and 6 months [531.0 (128.5 to 1186.0)] after cell therapy. A chest X-ray of the 20 patients that completed follow-up revealed a cardiothoracic index of $0.6 \pm 0.08$ at baseline, $0.566 \pm 0.062$
$(P=0.007)$ at 2-month follow-up, and $0.574 \pm 0.064(P>$ $0.05)$ at 6-month follow-up.

LVEF determined by the echocardiogram using Simpson's rule is illustrated in Figure 1A. There was no significant variation after cell injection (23.8 \pm 5.3 at baseline vs 25.0 \pm 7.7 at 6 months). The insets show individual values for LVEF during follow-up. MRI analyses showed that neither LVEF (Figures 1B; $19.6 \pm 5.9$ at baseline vs $20.2 \pm 9.6$ at 6 months) nor mean systolic (287.7 \pm 94.1 at baseline $v s$ $297.7 \pm 120.2$ at 6 months) or diastolic (355.7 \pm 108.4 at baseline vs $368.0 \pm 138.2$ at 6 months) diameters changed significantly during the 6-month follow-up.

Mean BNP levels showed a significant decrease 2 months after cell therapy, decreasing from $410.6 \mathrm{pg} / \mathrm{mL}$ at baseline to $317.4 \mathrm{pg} / \mathrm{mL}(P<0.001)$. This decrease was not sustained at 6 months when BNP levels reached 326 $\mathrm{pg} / \mathrm{mL}(\mathrm{P}=0.07$ vs baseline $)$.

CPET analysis revealed that maximal oxygen consumption increased significantly compared to baseline after cell therapy. Figure 2A shows variation in maximal oxygen consumption, with mean values increasing from $12.2 \pm 2.41$ $\mathrm{mL} \cdot \mathrm{kg}^{-1} \cdot \mathrm{min}^{-1}$ at baseline to $15.8 \pm 7.1 \mathrm{~mL} \cdot \mathrm{kg}^{-1} \cdot \mathrm{min}^{-1}$ at 6 months after cell therapy. Figure $2 \mathrm{~B}$ shows the percentage of patients with $\mathrm{VO}_{2}$ peak below $14 \mathrm{~mL} \cdot \mathrm{kg}^{-1} \cdot \mathrm{min}^{-1}$ (threshold for cardiac transplantation) at baseline and 6 months ( $P=$ 0.03 ) after cell therapy. Exercise duration normalized to the values obtained at baseline also showed a significant gain after cell therapy $(29.2 \%$ at 2 months and $51.0 \%$ at 6 months, $P=0.003$ and $P=0.01$ ). The six-minute walk test showed improvement in mean values ranging from $377.2 \pm 85.4 \mathrm{~m}$ at baseline to $441.1 \pm 85.3 \mathrm{~m}$ at 2 months $(P=0.03)$, and $444.1 \pm 77.9 \mathrm{~m}$ at 6 months $(P=0.01$; Figure $2 \mathrm{C})$.

Patients also had a significant improvement in NYHA class (Figure $3 A$ ) and quality of life measured by the Min-

Table 1. Clinical and hemodynamic characteristics of 24 patients with idiopathic dilated cardiomyopathy.

\begin{tabular}{lc}
\hline Age (years) & $46.0 \pm 11.6$ \\
Gender (male) & $17(70.8)$ \\
NYHA functional class & \\
II & $6(25.0)$ \\
III & $14(58.3)$ \\
IV & $4(16.7)$ \\
Left ventricular ejection fraction by & $23.1 \pm 5.4$ \\
echocardiogram (Simpson's rule, \%) & \\
Heart rate (bpm) & $73.0(63.5-80.0)$ \\
Systolic blood pressure (mmHg) & $102.5(90.0-110.0)$ \\
Diastolic blood pressure (mmHg) & $60.0(60.0-72.5)$ \\
Weight (kg) & $75.15 \pm 17.44$ \\
\hline
\end{tabular}

Data are reported as means $\pm S D$, median (interquartile range) or $\mathrm{N}$ (percent expressed). NYHA = New York Heart Association. 

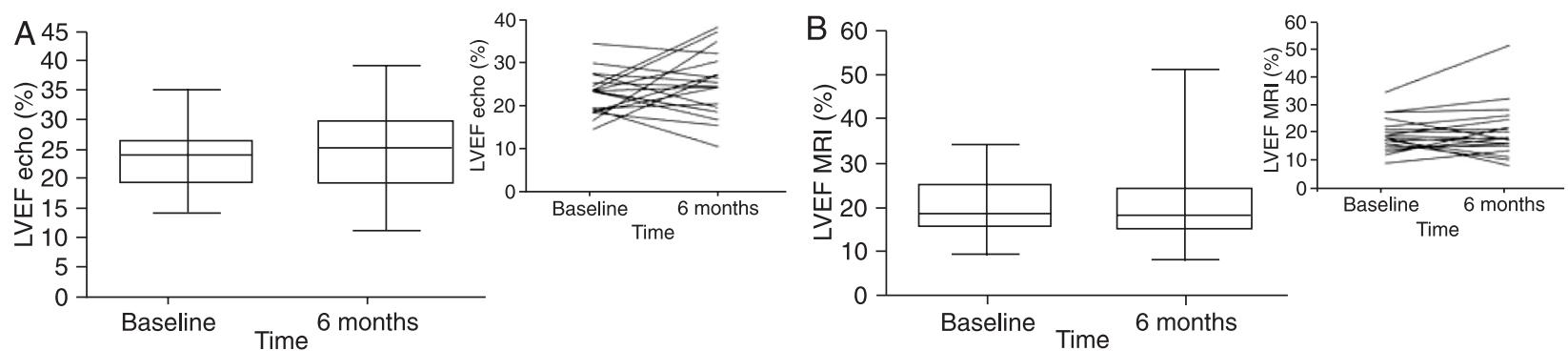

Figure 1. Left ventricular ejection fraction (LVEF) of patients with idiopathic dilated cardiomyopathy at baseline and after 6 months of cell therapy measured by (A) echocardiogram (echo) and (B) magnetic resonance imaging (MRI). Data are reported as median, interquartile intervals $(25-75 \%)$ and minimum and maximum values for each measured variable. $P>0.05$ vs baseline (Wilcoxon test). The insets show individual variations for the patients who completed follow-up.
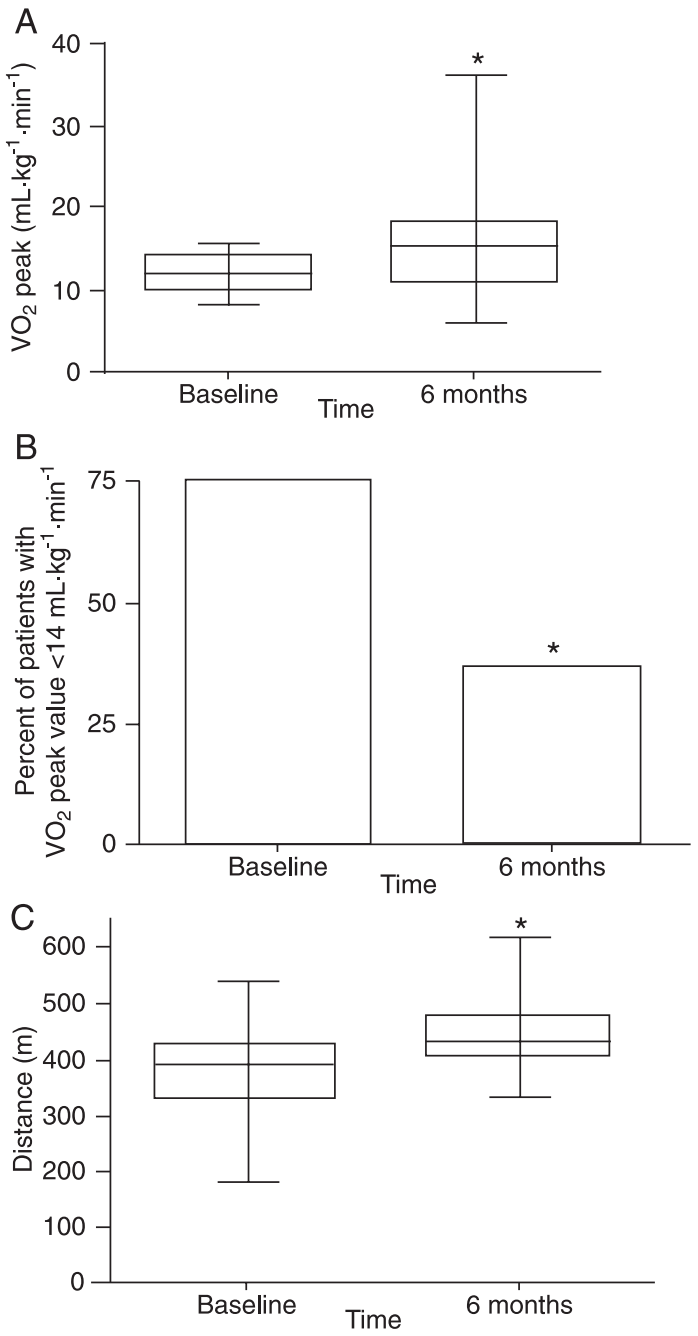

Figure 2. $A$, Mean maximal oxygen consumption $\left(\mathrm{VO}_{2}\right.$ peak $)$ determined by a cardiopulmonary test. $B$, Percent of patients with $\mathrm{VO}_{2}$ peak lower than $14 \mathrm{~mL} \cdot \mathrm{kg}^{-1} \cdot \mathrm{min}^{-1}(\mathrm{P}<0.001$, chi-square test). $C$, Mean distance walked by patients in the six-minute walk test (m). For $A$ and $C$, data are reported as median, interquartile intervals $(25-75 \%)$ and minimum and maximum values for each measured variable. ${ }^{*} \mathrm{P}<0.05$ vs baseline using the Student $t$-test.

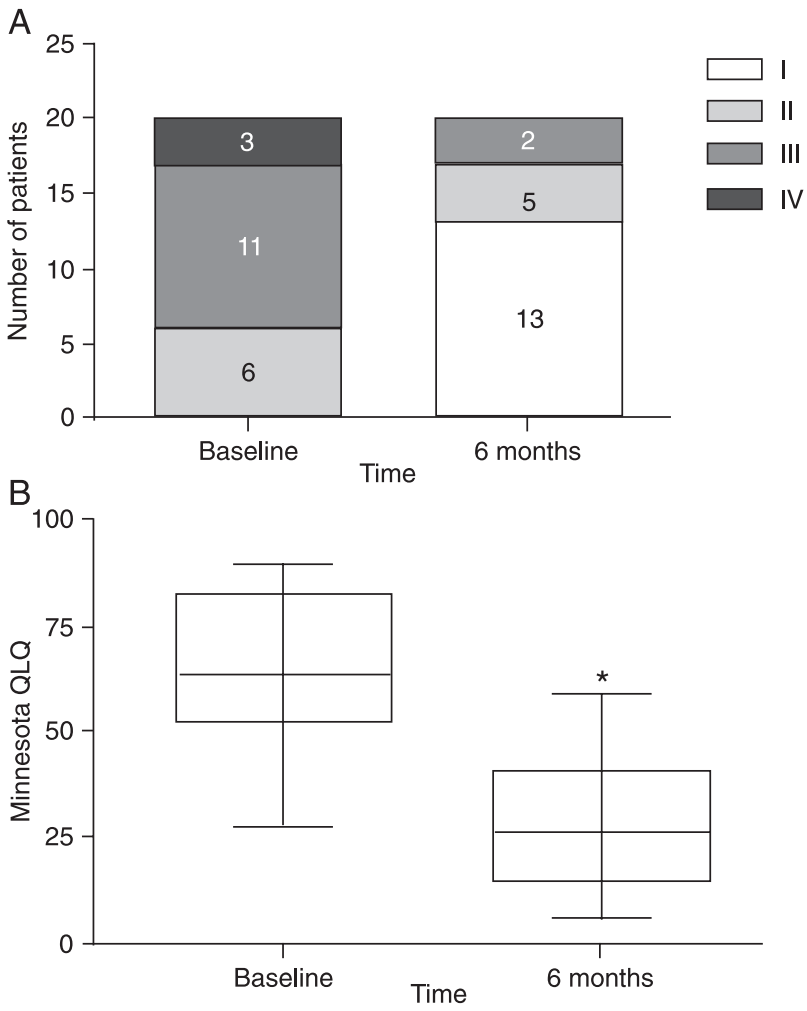

Figure 3. Quality of life evaluation. $A$, Distribution of patients with idiopathic dilated cardiomyopathy in each of four NYHA classes at baseline and 6 months after cell therapy $(P<0.001$ vs baseline, chi-square test). $B$, Score on the Minnesota Quality of Life Questionnaire (QLQ) at baseline and 6 months after treatment. Data are reported as median, interquartile intervals (25-75\%) and minimum and maximum values for each measured variable. ${ }^{*} \mathrm{P}<$ 0.005 vs baseline (paired Student $t$-test). 
nesota Questionnaire $(P=0.005)$ following cell therapy $(63 \pm 17.9$ at baseline vs $28.8 \pm 16.7$ at 6 months; Figure $3 \mathrm{~B})$. While at baseline the majority of patients (14) were in classes III and IV, after therapy 13 of the 20 patients were in class I (Figure 3A; $\mathrm{P}<0.001)$.

\section{Discussion}

Safety reports for cell therapy in dilated cardiomyopathy are contradictory. No adverse events have been reported in a trial where mononuclear cells were delivered to the coronary arteries in 24 patients after coronary sinus occlusion (19). Another trial used the intramyocardial route to deliver cells during thoracotomy, but only 5 IDC patients were included in the trial that reported 7 episodes of ventricular fibrillation during the procedure and 2 deaths by the same mechanism during the perioperative period (18). A third trial was interrupted for safety reasons after performing mononuclear cell injection by catheterization with balloon inflation in two patients (20). However, Fischer-Rasokat et al. (21) recently reported intracoronary delivery of cells using balloon inflation in 33 patients to be safe.

The present study indicates that intracoronary delivery of autologous mononuclear cells from bone marrow is safe and feasible in the IDC setting. Two of the three adverse events observed in the 24 patients involved atrial fibrillation and a transient right bundle branch block. The third event, an increase in troponin I levels, may have been directly associated with cell delivery but the patient was asymptomatic and hemodynamically stable without ECG changes. At any rate, this should lead to increased caution during the procedure.

Although there was considerable variability in ectopic beats during all phases of the study, including baseline, we did not observe an increase in ventricular or supraventricular ectopic beats during Holter monitoring after cell therapy. This confirms reported literature results indicating that intracoronary injection of bone marrow-derived cells is not arrhythmogenic (11,14-16,24).

The number of deaths observed during the 6-month follow-up of this study (4 of the 24 patients) is compatible with the disease state presented by the patients, since mean ejection fraction was below $25 \%$ as determined by ECG and $20 \%$ by MRI (25). Furthermore, Seth et al. (19) have reported identical mortality in a cell therapy trial for patients with non-ischemic dilated cardiomyopathy. Considering the time interval between the procedure and the occurrence of deaths by pulmonary edema and cardiogenic shock, the severity of the heart failure of the patients at enrollment and the natural history of the disease, we consider these deaths most likely not to be related to the cell injection procedure. As for the patient who died at home, arrhythmias related to cell injection leading to sudden cardiac death cannot be ruled out. Unfortunately, no autopsies were authorized by the families.
The study was not designed to test for efficacy, but functional and life quality parameters were evaluated at 2 and 6 months after cell therapy. Cardiac function, as determined by ECG and MRI showed no improvement in mean ejection fraction. This is in contrast to the results reported by Seth et al. (19) and Fischer-Rasokat et al. (21), who detected a significant increase in ejection fraction (EF) after cell therapy. Seth at al. (19) found, by ECG, an increase of $5.4 \%$ in EF\% after 6 months in 24 patients who had received cell therapy. Fischer-Rasokat et al. (21) reported a $3.2 \%$ increase in LVEF by ventriculography 3 months after cell delivery. A small percentage of the patients in our study (26\%) also showed improvement of $5 \%$ or more in EF\% 6 months after cell therapy. Furthermore, in both Seth's and Fischer-Rasokat's studies some of the patients showed no improvement in EF\%. This variability in individual response to therapy raises the question about which variables could influence cell therapy outcome. In the small population studied here we were not able to correlate improvement in LVEF to any other variable that might be relevant for the outcome of this therapy, such as age, gender, number of injected cells, percentage of CD34+ ${ }^{+}$cells or baseline LVEF, using a univariate model. Colony-forming assays of the injected cells were not performed and therefore we could not correlate this variable to regional contractile function as done by Fischer-Rasokat et al. (21).

The cardiopulmonary evaluation of the patients using CPET showed significant improvement after cell therapy in most variables analyzed: maximal oxygen consumption, time of exercise and $\mathrm{VE} / \mathrm{VCO}_{2}$ (data not shown). Especially important was the reduction of the number of patients with maximal oxygen consumption below the threshold for cardiac transplantation $\left(14 \mathrm{~mL} \cdot \mathrm{kg}^{-1} \cdot \mathrm{min}^{-1}\right)$, which declined from $75 \%$ at baseline to $36.8 \% 6$ months after cell therapy. Even if we consider the more strict recommendation of $\mathrm{VO}_{2}$ peak below $12 \mathrm{~mL} \cdot \mathrm{kg}^{-1} \cdot \mathrm{min}^{-1}$ for the indication of heart transplantation in patients under $\beta$-blocker therapy (the majority of our patients), cell therapy still reduced the number of patients with $\mathrm{VO}_{2}$ peak below this threshold at baseline from $50 \%$ (10 of 20 patients) to $25 \%$ (5 of 20 patients) 6 months after cell delivery. In agreement with the increase in cardiopulmonary function, more qualitative parameters such as NYHA classification and Minnesota Quality of Life Questionnaire showed significant improvements after cell therapy.

Cell therapy using bone marrow-derived cells has been successfully applied to the treatment of acute and chronic ischemic heart disease $(15,16,26)$. Since the pioneering work of Strauer et al. (27), many groups have performed phase I/II trials showing the intracoronary delivery of autologous marrow cells to be safe and potentially effective $(16,26,27)$. Larger randomized trials have confirmed the efficacy of this new therapy (28-30), although these results have been disputed (31). The beneficial effects of cell therapy in the setting of ischemic heart disease are not 
fully understood, and proposed mechanisms of action have included new myocyte formation, angiogenesis and secretion of trophic and anti-apoptotic factors by the mononuclear cell fraction of bone marrow $(17,32)$. The capacity of bone marrow cells to regenerate myocytes has been a matter of intense debate $(7,17,32-36)$. This safety trial indicates a broad variability in results for individual patients. Certainly a better understanding of the mechanisms of action will improve our capacity to apply bone marrow-derived cell therapies to patients with dilated cardiomyopathy. In conclusion, our findings agree with published results, showing that

\section{References}

1. Johnson RA, Palacios I. Dilated cardiomyopathies of the adult (first of two parts). N Engl J Med 1982; 307: 10511058.

2. Maron BJ, Towbin JA, Thiene G, Antzelevitch C, Corrado D, Arnett $\mathrm{D}$, et al. Contemporary definitions and classification of the cardiomyopathies: an American Heart Association Scientific Statement from the Council on Clinical Cardiology, Heart Failure and Transplantation Committee; Quality of Care and Outcomes Research and Functional Genomics and Translational Biology Interdisciplinary Working Groups; and Council on Epidemiology and Prevention. Circulation 2006; 113: 1807-1816.

3. Miller LW, Missov ED. Epidemiology of heart failure. Cardiol Clin 2001; 19: 547-555.

4. Chen M, Fan ZC, Liu XJ, Deng JL, Zhang L, Rao L, et al. Effects of autologous stem cell transplantation on ventricular electrophysiology in doxorubicin-induced heart failure. Cell Biol Int 2006; 30: 576-582.

5. Fuchs S, Baffour R, Zhou YF, Shou M, Pierre A, Tio FO, et al. Transendocardial delivery of autologous bone marrow enhances collateral perfusion and regional function in pigs with chronic experimental myocardial ischemia. J Am Coll Cardiol 2001; 37: 1726-1732.

6. Nagaya N, Kangawa K, Itoh T, Iwase T, Murakami S, Miyahara $\mathrm{Y}$, et al. Transplantation of mesenchymal stem cells improves cardiac function in a rat model of dilated cardiomyopathy. Circulation 2005; 112: 1128-1135.

7. Orlic D, Kajstura J, Chimenti S, Jakoniuk I, Anderson SM, $\mathrm{Li} \mathrm{B}$, et al. Bone marrow cells regenerate infarcted myocardium. Nature 2001; 410: 701-705.

8. Soares MB, Lima RS, Rocha LL, Takyia CM, Pontes-de-Carvalho $\mathrm{L}$, de Carvalho AC, et al. Transplanted bone marrow cells repair heart tissue and reduce myocarditis in chronic chagasic mice. Am J Pathol 2004; 164: 441-447.

9. Sun CK, Chang LT, Sheu JJ, Chiang CH, Lee FY, Wu CJ, et al. Bone marrow-derived mononuclear cell therapy alleviates left ventricular remodeling and improves heart function in rat-dilated cardiomyopathy. Crit Care Med 2009; 37: 11971205.

10. Abdel-Latif A, Bolli R, Tleyjeh IM, Montori VM, Perin EC, Hornung CA, et al. Adult bone marrow-derived cells for cardiac repair: a systematic review and meta-analysis. Arch Intern Med 2007; 167: 989-997.

11. Bartunek J, Dimmeler S, Drexler H, Fernandez-Aviles F, cell therapy is safe and feasible, also in the setting of dilated cardiomyopathy. Larger, randomized, double-blind and placebo-controlled trials are necessary to test for efficacy and the present study laid the groundwork for such a trial, which we are currently performing (NCT 00333827).

\section{Acknowledgments}

Research supported by Instituto do Milênio em Bioengenharia Tecidual, CNPq, Ministério de Ciência de Tecnologia (MCT), FAPERJ and Ministério da Saúde.
Galinanes M, Janssens S, et al. The consensus of the task force of the European Society of Cardiology concerning the clinical investigation of the use of autologous adult stem cells for repair of the heart. Eur Heart J 2006; 27: 1338-1340.

12. Burt RK, Loh Y, Pearce W, Beohar N, Barr WG, Craig R, et al. Clinical applications of blood-derived and marrow-derived stem cells for nonmalignant diseases. JAMA 2008; 299: 925936.

13. Lipinski MJ, Biondi-Zoccai GG, Abbate A, Khianey R, Sheiban I, Bartunek J, et al. Impact of intracoronary cell therapy on left ventricular function in the setting of acute myocardial infarction: a collaborative systematic review and meta-analysis of controlled clinical trials. J Am Coll Cardiol 2007; 50: 1761-1767.

14. Patel AN, Sherman W. Cardiac stem cell therapy: advances from 2008. Cell Transplant 2009; 18: 243-244.

15. Perin EC, Dohmann HF, Borojevic R, Silva SA, Sousa AL, Mesquita CT, et al. Transendocardial, autologous bone marrow cell transplantation for severe, chronic ischemic heart failure. Circulation 2003; 107: 2294-2302.

16. Silva SA, Sousa AL, Haddad AF, Azevedo JC, Soares VE, Peixoto CM, et al. Autologous bone-marrow mononuclear cell transplantation after acute myocardial infarction: comparison of two delivery techniques. Cell Transplant 2009; 18: 343-352.

17. van Laake LW, Hassink R, Doevendans PA, Mummery C. Heart repair and stem cells. J Physiol 2006; 577: 467-478.

18. Arguero R, Careaga-Reyna G, Castano-Guerra R, GarridoGarduno MH, Magana-Serrano JA, de Jesus Nambo-Lucio. Cellular autotransplantation for ischemic and idiopathic dilated cardiomyopathy. Preliminary report. Arch Med Res 2006; 37: 1010-1014.

19. Seth S, Narang R, Bhargava B, Ray R, Mohanty S, Gulati G, et al. Percutaneous intracoronary cellular cardiomyoplasty for nonischemic cardiomyopathy: clinical and histopathological results: the first-in-man ABCD (Autologous Bone Marrow Cells in Dilated Cardiomyopathy) trial. J Am Coll Cardiol 2006; 48: 2350-2351.

20. Widimsky P, Penicka M. Complications after intracoronary stem cell transplantation in idiopathic dilated cardiomyopathy. Int J Cardiol 2006; 111: 178-179.

21. Fischer-Rasokat U, Assmus B, Seeger FH, Honold J, Leistner $\mathrm{D}$, Fichtlscherer $\mathrm{S}$, et al. A pilot trial to assess potential effects of selective intracoronary bone marrow-derived 
progenitor cell infusion in patients with nonischemic dilated cardiomyopathy: final 1-year results of the transplantation of progenitor cells and functional regeneration enhancement pilot trial in patients with nonischemic dilated cardiomyopathy. Circ Heart Fail 2009; 2: 417-423.

22. Sutherland DR, Anderson L, Keeney M, Nayar R, Chin-Yee I. The ISHAGE guidelines for CD34+ cell determination by flow cytometry. International Society of Hematotherapy and Graft Engineering. J Hematother 1996; 5: 213-226.

23. Foundation for Statistical Computing VA. Development Core Team. R: A language and environment for statistical computing. http://www.R-project.org.

24. Vilas-Boas F, Feitosa GS, Soares MB, Mota A, Pinho-Filho $\mathrm{JA}$, Almeida AJ, et al. [Early results of bone marrow cell transplantation to the myocardium of patients with heart failure due to Chagas disease]. Arq Bras Cardiol 2006; 87: 159-166.

25. Effects of enalapril on mortality in severe congestive heart failure. Results of the Cooperative North Scandinavian Enalapril Survival Study (CONSENSUS). The CONSENSUS Trial Study Group. N Engl J Med 1987; 316: 1429-1435.

26. Assmus B, Schachinger V, Teupe C, Britten M, Lehmann $\mathrm{R}$, Dobert N, et al. Transplantation of Progenitor Cells and Regeneration Enhancement in Acute Myocardial Infarction (TOPCARE-AMI). Circulation 2002; 106: 3009-3017.

27. Strauer BE, Brehm M, Zeus T, Kostering M, Hernandez A, Sorg RV, et al. Repair of infarcted myocardium by autologous intracoronary mononuclear bone marrow cell transplantation in humans. Circulation 2002; 106: 1913-1918.

28. Janssens S, Dubois C, Bogaert J, Theunissen K, Deroose C, Desmet W, et al. Autologous bone marrow-derived stem-cell transfer in patients with ST-segment elevation myocardial infarction: double-blind, randomised controlled trial. Lancet
2006; 367: 113-121.

29. Schachinger V, Erbs S, Elsasser A, Haberbosch W, Hambrecht $\mathrm{R}$, Holschermann $\mathrm{H}$, et al. Intracoronary bone marrow-derived progenitor cells in acute myocardial infarction. N Engl J Med 2006; 355: 1210-1221.

30. Wollert KC, Meyer GP, Lotz J, Ringes-Lichtenberg S, Lippolt $\mathrm{P}$, Breidenbach $\mathrm{C}$, et al. Intracoronary autologous bonemarrow cell transfer after myocardial infarction: the BOOST randomised controlled clinical trial. Lancet 2004; 364: 141148.

31. Lunde K, Solheim S, Aakhus S, Arnesen H, Abdelnoor M, Egeland $\mathrm{T}$, et al. Intracoronary injection of mononuclear bone marrow cells in acute myocardial infarction. $N$ Engl $J$ Med 2006; 355: 1199-1209.

32. Leri A, Kajstura J, Anversa P. Cardiac stem cells and mechanisms of myocardial regeneration. Physiol Rev 2005; 85: 1373-1416.

33. Balsam LB, Wagers AJ, Christensen JL, Kofidis T, Weissman IL, Robbins RC. Haematopoietic stem cells adopt mature haematopoietic fates in ischaemic myocardium. Nature 2004; 428: 668-673.

34. Murry CE, Soonpaa MH, Reinecke H, Nakajima H, Nakajima $\mathrm{HO}$, Rubart M, et al. Haematopoietic stem cells do not transdifferentiate into cardiac myocytes in myocardial infarcts. Nature 2004; 428: 664-668.

35. Nygren JM, Jovinge S, Breitbach M, Sawen P, Roll W, Hescheler J, et al. Bone marrow-derived hematopoietic cells generate cardiomyocytes at a low frequency through cell fusion, but not transdifferentiation. Nat Med 2004; 10: 494501.

36. Rota M, Kajstura J, Hosoda T, Bearzi C, Vitale S, Esposito $\mathrm{G}$, et al. Bone marrow cells adopt the cardiomyogenic fate in vivo. Proc Natl Acad Sci U S A 2007; 104: 17783-17788. 